\title{
Development, yield potential and nutritional aspects of resistant grapevine varieties in Trentino Alto Adige
}

\author{
Stefano Pedò ${ }^{1, *}$, Maurizio Bottura $^{1}$ and Duilio Porro ${ }^{1}$ \\ ${ }^{1}$ Technology Transfer Centre, Edmund Mach Foundation, via E. Mach 1, 38010 San Michele all'Adige, Italy
}

\begin{abstract}
The reduction of the environmental impact of agricultural activity has stimulated the evaluation of new cultivars tolerant/resistant to fungal diseases within the context of Trentino viticulture. In an alluvial soil, 15 varieties of resistant vines were planted: Aromera, Baron, Bronner, Cabernet Cantor, Cabernet Cortis, Cabernet Carbon, Cabino, Helios, Johanniter, Monarch, Muscaris, Prior, Regent, Solaris, and Souvignier gris. Since 2015 they have been evaluated for nutritional aspects, vegetative-productive balance, quantitative-qualitative parameters of musts and health status. Some cultivars (Cabernet Cortis, Cabino, Helios, and Prior) had an insufficient vegetative development, whilst other varieties presented a balanced or excessive behaviour. Regarding magnesium (Mg), some of these cultivars presented deficiencies, often confirmed by visual analysis, but not always highlighted by leaf analyses (Cabernet Cantor, Cabernet Cortis, and Monarch). For such varieties, Mg supply is recommended. Nonetheless, with the aim of new plantings, the choice of more suitable rootstock combinations should be done. Cabino always showed very highly susceptibility to Plasmopara viticola attack, with an ineffective resistance.
\end{abstract}

\section{Introduction}

In the last few years, one of the goals of agricultural production processes is the reduction of environmental impact. Both consumers and producers are seeking out solutions with lower impact, allowing for enhanced value of the final product $[1,2,3]$.

In Italy, the application phase of Directive 2009/128 EC on the sustainable use of pesticides - National Action Plans (NAPs) - often more stringent in their local application, is also aimed at finding solutions that are less impactful from an environmental point of view [4]. In grapevines, recently, the search for valid alternatives to the typically cultivated varieties of Vitis vinifera has identified new resistant and/or tolerant genotypes to the main cryptogams (in particular downy and powdery mildew). These cultivars represent the result of interspecific crossings, obtained from some important European research centers in viticulture, using cultivars of Vitis vinifera and other Vitis of American and Asian origins. They can be used by grapevine producers as a relevant solution for less intensive and more environment friendly viticulture.

Currently, only about twenty of these cultivars are registered in the Italian catalog, half of them obtained from State Viticultural Institute of Freiburg (D) and another half from the Institute of Applied Genomics of Udine (I).

Their registration is often restricted to specific geographical areas of cultivation and, in any case, they cannot be used for wines with a designation of origin (due to the article 6 of Legislative Decree 2010/61).

The production of wines from these resistant/tolerant varieties, although still very limited from the point of view of the areas invested, is assuming its relevance and visibility in Germany, Austria, and South Tirol, thanks to an association of viticulturists named PIWI, German acronym of pilzwiderstandsfähig that means fungus resistant [5].

Alternatively, these cultivars may represent a solution for growing plants in those farm portions where the phytosanitary treatment conflicts with sensitive areas protected by the NAPs, in which carrying out several fungicide treatments represents an objective difficulty for the grapevine producers.

\section{Materials and methods}

\subsection{Collections description}

In 2013, a Pergola trained varietal collection was created in Trentino at Vallagarina (Rovereto, lat.: $46^{\circ} 52^{\prime} 37.96$ "N, long.: $11^{\circ} 01^{\prime} 14.03 " \mathrm{E}, 220 \mathrm{~m}$ a.s.l. - at a vine spacing of a $3.00 \mathrm{~m}$ between-row x $0.77 \mathrm{~m}$ in-row). The following 11 registered varieties were planted: Bronner (W = white berry), Cabernet Cantor ( $\mathrm{B}=$ black berry), Cabernet Carbon (B), Cabernet Cortis (B), Helios (W), Johanniter (W), Monarch (B), Muscaris (W), Prior (B), Solaris (W), and Souvignier gris (W). In addition to these Aromera (W, unregistered prototype of Innovitis of

* Corresponding author: stefano.pedo@fmach.it 
Bolzano), Baron (B, Institute of Freiburg), Cabino (B, breeder: George Weiss, Austria), and Regent (W, Julius Kühn- Institute of Geilweirhof) were also present.

The soil of cultivation is a typical alluvial of the Adige plain, sandy, sub-alkaline, extremely calcareous (420 $\mathrm{g} / \mathrm{kg})$, with good content of active limestone $(38 \mathrm{~g} / \mathrm{kg})$, organic matter $(2.3 \%)$, very rich in phosphorus (52 $\mathrm{mg} / \mathrm{kg})$ and magnesium $(330 \mathrm{mg} / \mathrm{kg})$ and with medium potassium content $(84 \mathrm{mg} / \mathrm{kg})$ and a high $\mathrm{Mg} / \mathrm{K}$ ratio.

\subsection{Assessments and analyses}

Starting from 2015, the experimental protocol provided for the analyses of the leaf nutritional status and musts for technological ripening parameters (the latter were made only on 14 varieties). In the three-year period between 2015 and2017, fifteen plants for each cultivar were evaluated at fruit set (BBCH 71-73 [6]), with regard to nutritional aspects through leaf analyses and SPAD indexes (Konica Minolta). On leaf samples, nitrogen $(\mathrm{N})$ was determined by the Dumas total combustion method, whilst for other elements concentration - phosphorus (P), potassium (K), Calcium $(\mathrm{Ca}), \mathrm{Mg}$, iron (Fe), manganese $(\mathrm{Mn})$, boron $(\mathrm{B})$, copper $(\mathrm{Cu})$, zinc $(\mathrm{Zn})$, and sulfur (S) - the ICP-OES plasma emission spectrometry analysis was used. Readings related to SPAD measurements were done on two leaves/plant (30 cases/cultivar) .

On the same vines, the photosynthetically active biomass (NDVI index) was measured using the Spectrosense 2+ instrument (Skye Instruments Ltd).

Yield components (i.e. cluster and shoot number, yield per vine and other derived parameters) from each monitored plant were measured, while the qualitative parameters of the must $\left({ }^{\circ}\right.$ Brix, titratable acidity - TA, $\mathrm{pH}$, malic acid, tartaric acid, potassium, and yeast assimilable nitrogen - YAN) were determined by FT-IR spectrophotometer (FOSS Analytical) on a sample averaged by all the collected plants with a weight of 1.5 $\mathrm{kg}$.

Due to the growth habit of these cultivars, which was not homogeneous, further data were collected in order to acquire more precise information regarding their vegetative-productive expression. With this aim, classical agronomic indexes were measured: length and number of shoots, and number of secondary shoots. Only in 2017, the Point quadrat method [7,8] was applied at veraison, supplemented by the estimation of growth development using point cards $[7,8]$.

In each growing season, the appearance of symptoms related to the main fungal diseases was monitored. No antifungal treatments were carried out to protect the vines, regardless of the fact that normal management recommends at least 1-3 treatments.

The frost event that hit northern Italy between 19 and 21 April 2017 caused serious damage to the already developing buds and shoots, stimulating the plants to sprout from latent or secondary buds, which are usually less fruitful than the primary buds. Therefore, yield data will be limited to 2015-16 seasons.
All data were statistically processed using STATISTICA statistical packages (version 13.0), separating the averages by Tukey test. In the text, the values that are statistically different to this test are indicated by different letters. The levels of significance reported and indicated with n.s., *, **, ***, representing not significant, significance for values of $\mathrm{P} \leq 0.05$ and $\mathrm{P} \geq 0.01, \mathrm{P}<0.01$ and $\mathrm{P} \geq 0.001, \mathrm{P}<0.001$, respectively.

\section{Results and discussion}

For the sake of brevity, complete nutritional data are not reported, only those that are significant from a statistical point of view will be discussed. All annual analytical data related to the leaf mineral elements concentration was used as a replicate due to the fact that only single values are available for each combination.

Regarding macroelements, only $\mathrm{N}, \mathrm{K}$ and $\mathrm{Mg}$ showed significant differences among the cultivars, whereas $\mathrm{Fe}$ and $\mathrm{B}$ were the microelements displaying differences.

Regent proved to be the variety with the highest $\mathrm{N}$ level (3.1\% d.w.) compared to Cabino $(2.14 \%)$, Solaris (1.98\%), Muscaris (2.29\%), and Cabernet Cortis $(2.26 \%)$, which showed the lowest levels (values of $\mathrm{P} \leq$ $0.05)$. Solaris shows $\mathrm{N}$ at deficient levels compared to the reference standards [9], suggesting that this cultivar requires higher levels of $\mathrm{N}$ fertilization than the other varieties. Some of these genotypes, such as Solaris and Cabernet Cortis, characterized by low N levels, also have low SPAD values and pale green colorations detectable by eye.

The leaf $\mathrm{Mg}$ levels were lower than the standard minimum threshold [9] for four cultivars: Bronner $(0.16 \%)$, Helios $(0.20 \%)$, Souvignier gris $(0.19 \%)$, and Johanniter $(0.19 \%)$; the first three also showed visual $\mathrm{Mg}$ deficiency symptoms.

A special notice should be made for both Cabernet Cantor and Monarch, which have shown, in all years, visual $\mathrm{Mg}$ deficiencies, although leaf concentrations were above the limit $(0.20-0.39 \%)$, with values respectively equal to $0.28 \%$ and $0.22 \%$.

No cultivar showed average leaf Fe levels below the limit reference range $(60-130 \mathrm{mg} / \mathrm{kg})$. Although limits of the foliar diagnosis of iron are known, Johanniter $(92$ $\mathrm{mg} / \mathrm{kg}$ ) and Regent $(94 \mathrm{mg} / \mathrm{kg}$ ) were characterized by the highest values of this ion, much higher $(\mathrm{P}$ values $\leq 0.05)$ compared to Souvignier gris, which always had lower concentrations throughout the three-year period (65 $\mathrm{mg} / \mathrm{kg}$ ).This result is partially confirmed by the visual assessment, which highlighted the unequivocal $\mathrm{Fe}$ deficiency in this cultivar. Cabernet Cortis $(76 \mathrm{mg} / \mathrm{kg})$, Cabino $(70 \mathrm{mg} / \mathrm{kg}$ ), and Prior $(78 \mathrm{mg} / \mathrm{kg}$ ) also showed visual symptoms of light chlorosis attributable to $\mathrm{Fe}$ deficiency. No variety had any B deficiency, although Baron (21 mg/kg), Regent (20 mg/kg), Prior (24 mg/kg), and Cabino $(27 \mathrm{mg} / \mathrm{kg})$ showed significantly lower values $(\mathrm{P} \leq 0.05)$ compared to those found in both Cabernet Carbon $(47 \mathrm{mg} / \mathrm{kg})$ and Cabernet Cortis $(56$ $\mathrm{mg} / \mathrm{kg}$ ), which instead showed, on average, high levels. The exploratory analysis (EFA, Exploratory Factor Analysis made by using Principal Component Analysis - 
PCA) of NDVI and SPAD and of the nutritional data related to them in the correlation matrix, extracts two factors able to explain $64.5 \%$ of the cumulative variance (figure 1).

Factor 1 is negatively correlated with $\mathrm{SPAD}, \mathrm{N}, \mathrm{Ca}, \mathrm{Fe}$, and $\mathrm{S}$, while factor 2 positively with NDVI and $\mathrm{Mg}$.

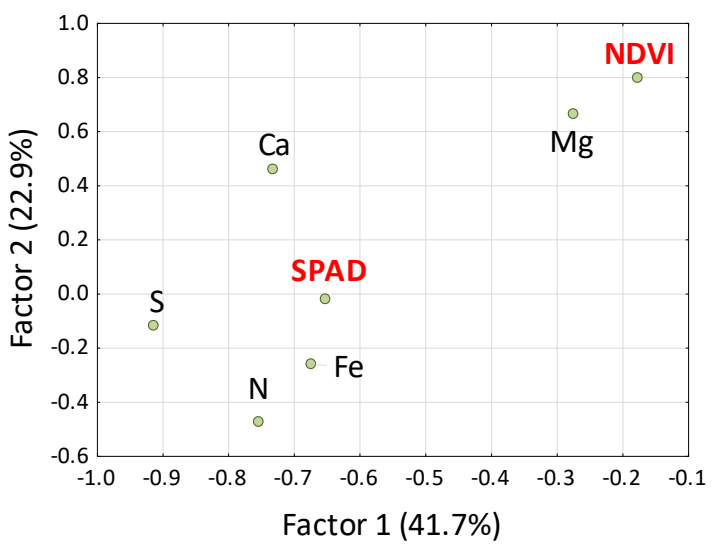

Fig. 1: Exploratory Factor Analysis (PCA)

This graphic outlay shows that NDVI values are more discriminated by $\mathrm{Mg}$ content, while SPAD index is coherently influenced by the values of $\mathrm{N}, \mathrm{Fe}$, and $\mathrm{S}$.

The three-year average relative to NDVI index (figure 2) allows a sorting of the cultivars according to the photosynthetically active biomass values, even if the high variability of the weaker cultivars offsets the statistical significance.

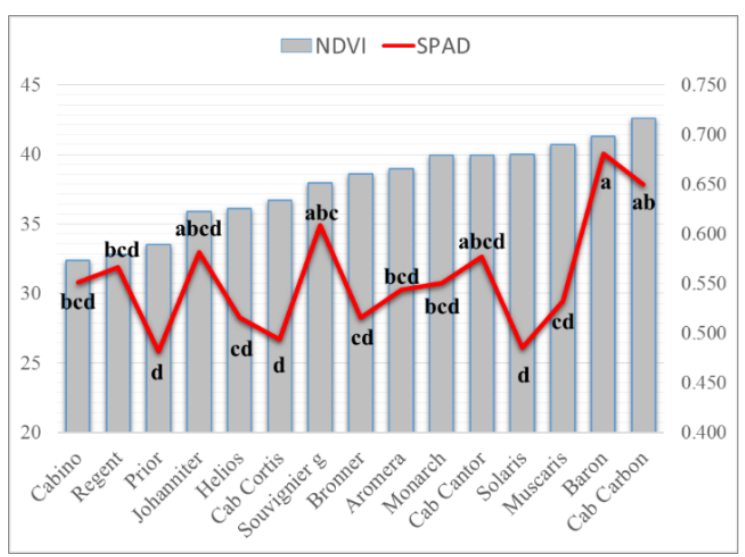

Fig. 2: mean values of NDVI and SPAD indices (2015-2017)

The data deriving from the Point Quadrat method (table 1) are shown by averaging the three insertion canopy zones: basal, median and apical. This reading is appropriate for those cultivars that are able to fill all the space available on the pergola. Otherwise, the interpretation of the disaggregated data by distinguishing different area may be more illuminating.

Cabino, Prior and, partially, Helios, show an insufficient development of the shoots, a reduced number of leaf layers and leaves with clear symptoms of nutritional deficiencies.
Table 1: Point Quadrat analysis (2017)

\begin{tabular}{|l|c|c|c|}
\hline Variety & $\begin{array}{c}\text { Mean } \\
\text { number } \\
\text { of leaf } \\
\text { layers }\end{array}$ & $\begin{array}{c}\text { Vegetation } \\
\text { gaps } \\
\mathbf{( \% )}\end{array}$ & $\begin{array}{c}\text { Internal } \\
\text { leaves } \\
\mathbf{( \% )}\end{array}$ \\
\hline \hline Aromera & $1.96 \mathrm{abcde}$ & $15.69 \mathrm{bc}$ & $24.51 \mathrm{ab}$ \\
\hline Baron & $2.55 \mathrm{abcd}$ & $13.73 \mathrm{bc}$ & $43.50 \mathrm{a}$ \\
\hline Bronner & $1.67 \mathrm{bcde}$ & $17.65 \mathrm{bc}$ & $23.08 \mathrm{ab}$ \\
\hline Cab. Cantor & $1.25 \mathrm{abc}$ & $29.41 \mathrm{bc}$ & $21.16 \mathrm{ab}$ \\
\hline Cab. Carbon & $2.61 \mathrm{bcde}$ & $3.92 \mathrm{abc}$ & $39.41 \mathrm{ab}$ \\
\hline Cab. Cortis & $1.59 \mathrm{bcde}$ & $25.49 \mathrm{abc}$ & $22.41 \mathrm{ab}$ \\
\hline Cabino & $0.78 \mathrm{de}$ & $49.02 \mathrm{bc}$ & $6.30 \mathrm{~b}$ \\
\hline Helios & $0.96 \mathrm{cde}$ & $49.02 \mathrm{ab}$ & $14.55 \mathrm{ab}$ \\
\hline Johanniter & $2.88 \mathrm{ab}$ & $9.80 \mathrm{bc}$ & $43.48 \mathrm{a}$ \\
\hline Monarch & $1.61 \mathrm{bcde}$ & $13.73 \mathrm{bc}$ & $13.60 \mathrm{ab}$ \\
\hline Muscaris & $3.57 \mathrm{a}$ & $0.00 \mathrm{c}$ & $48.20 \mathrm{a}$ \\
\hline Prior & $0.69 \mathrm{e}$ & $70.59 \mathrm{a}$ & $14.40 \mathrm{ab}$ \\
\hline Regent & $2.27 \mathrm{abcde}$ & $11.76 \mathrm{bc}$ & $35.73 \mathrm{ab}$ \\
\hline Solaris & $2.90 \mathrm{abcde}$ & $3.92 \mathrm{bc}$ & $39.31 \mathrm{ab}$ \\
\hline Souvignier g. & $2.10 \mathrm{abcde}$ & $13.73 \mathrm{bc}$ & $29.66 \mathrm{ab}$ \\
\hline \hline Significance & $* * *$ & $* * *$ & $* *$ \\
\hline
\end{tabular}

The analysis of data distinguished by the different areas of the canopy wall highlights for Cabino $41.2 \%, 35.3 \%$ and $70.6 \%$ of gaps respectively for basal, median and apical zones; for Prior, 41.2\%, 70.6\% and $100 \%$; for Helios $17.6 \%, 52.9 \%$, and $76.5 \%$. A group of varieties composed by Aromera, Bronner, Cabernet Carbon, Cabernet Cortis, Monarch, and Souvignier gris was found to have an average number of leaf layers between 1.25 and 2.10. In any case, it should be pointed out that in varieties such as Cabernet Cantor, the value of the average number of leaf layers (1.25) is likely too low as it also associates to excessive vegetation gaps. Finally, the group consisting of Baron, Cabernet Carbon, Johanniter, Muscaris, Regent, and Solaris have a high number of leaf layers. Among these cultivars, Muscaris and Baron have a vegetative excess, well evidenced by the high number of layers, low values of the vegetation gaps and high number of internal leaves. These foliar densities on the pergola can clearly reduce the canopy efficiency, given the high percentage of internal leaves that receives low levels of photosynthetically active radiation, resulting mainly from diffused light.

From the analysis of vegetative and productive data (table 2) a different behavior is observed: Regent is characterized by extreme vigor and low productivity, Baron also shows a low Ravaz index due, in this case, to a reduced fruit load.

Some varieties - Johanniter, Bronner, Cabernet Cortis, Monarch, Solaris and Souvignier gris - still present in their third year satisfying yield levels per hectare, whereas Baron, Cabino, Helios, Prior, and Regent show very low values of this parameter. Must composition reported in table 3 points out the possibility to reach, in a large majority of cultivars, a sufficient level of soluble solids. 
Table 2: Vegetative and productive data (2015-2016)

\begin{tabular}{|l|c|c|c|c|c|c|}
\hline Variety & $\begin{array}{c}\text { Clusters } \\
\text { /vine }\end{array}$ & $\begin{array}{c}\text { Yield/vine } \\
\mathbf{( g )}\end{array}$ & $\begin{array}{c}\text { Yield/ } \\
\text { hectare } \\
\text { (t) }\end{array}$ & $\begin{array}{c}\text { Pruning } \\
\text { wood } \\
\mathbf{( g )}\end{array}$ & $\begin{array}{c}\text { Ravaz } \\
\text { index }\end{array}$ & $\begin{array}{c}\text { Single cane } \\
\text { weight } \\
\text { (g) }\end{array}$ \\
\hline Aromera & $21 \mathrm{abcd}$ & $1384 \mathrm{def}$ & 6 & $364.6 \mathrm{abc}$ & $3.8 \mathrm{c}$ & $42.6 \mathrm{~b}$ \\
\hline Baron & $15.7 \mathrm{bcde}$ & $439 \mathrm{~g}$ & 2 & $361.4 \mathrm{abc}$ & $1.3 \mathrm{c}$ & $39.7 \mathrm{~b}$ \\
\hline Bronner & $23.9 \mathrm{ab}$ & $2494 \mathrm{ab}$ & 11 & $302.1 \mathrm{bc}$ & $9.6 \mathrm{bc}$ & $35.7 \mathrm{~b}$ \\
\hline Cabernet Cantor & $18.0 \mathrm{bcde}$ & $1867 \mathrm{bcde}$ & 8 & $311.3 \mathrm{bc}$ & $19.9 \mathrm{abc}$ & $34.7 \mathrm{~b}$ \\
\hline Cabernet Carbon & $18.9 \mathrm{abcde}$ & $1637 \mathrm{cde}$ & 7 & $265.4 \mathrm{bc}$ & $6.8 \mathrm{bc}$ & $26.8 \mathrm{bc}$ \\
\hline Cabernet Cortis & $24.8 \mathrm{ab}$ & $2524 \mathrm{ab}$ & 11 & $243.9 \mathrm{~cd}$ & $30.9 \mathrm{ab}$ & $26.1 \mathrm{bc}$ \\
\hline Cabino & $14.6 \mathrm{cde}$ & $707 \mathrm{fg}$ & 3 & $126.1 \mathrm{de}$ & $6.8 \mathrm{bc}$ & $30.0 \mathrm{bc}$ \\
\hline Helios & $12.6 \mathrm{de}$ & $657 \mathrm{fg}$ & 3 & $67.9 \mathrm{e}$ & $19.4 \mathrm{abc}$ & $10.7 \mathrm{c}$ \\
\hline Johanniter & $24.1 \mathrm{abc}$ & $3143 \mathrm{a}$ & 14 & $311.4 \mathrm{bc}$ & $10.6 \mathrm{abc}$ & $38.4 \mathrm{~b}$ \\
\hline Monarch & $18.0 \mathrm{bcde}$ & $2636 \mathrm{ab}$ & 11 & $282.9 \mathrm{bc}$ & $10.4 \mathrm{bc}$ & $33.9 \mathrm{~b}$ \\
\hline Muscaris & $21.6 \mathrm{abc}$ & $1967 \mathrm{bcd}$ & 9 & $366.1 \mathrm{abc}$ & $5.8 \mathrm{bc}$ & $39.0 \mathrm{~b}$ \\
\hline Prior & $12.0 \mathrm{e}$ & $1262 \mathrm{defg}$ & 5 & $89.6 \mathrm{e}$ & $38.6 \mathrm{a}$ & $13.6 \mathrm{c}$ \\
\hline Regent & $14.6 \mathrm{bcde}$ & $953 \mathrm{efg}$ & 4 & $518.6 \mathrm{a}$ & $2.0 \mathrm{c}$ & $92.8 \mathrm{a}$ \\
\hline Solaris & $27.1 \mathrm{a}$ & $2411 \mathrm{ab}$ & 10 & $390 \mathrm{ab}$ & $7.8 \mathrm{bc}$ & $36.4 \mathrm{~b}$ \\
\hline Souvignier gris & $18.1 \mathrm{bcde}$ & $2291 \mathrm{abc}$ & 10 & $300 \mathrm{bc}$ & $9.0 \mathrm{bc}$ & $35.7 \mathrm{~b}$ \\
\hline Significance & $* * *$ & $* *$ & - & $* *$ & $* * *$ & $* *$ \\
\hline
\end{tabular}

Monarch represents the only exception. In fact, this cultivar did not reach a satisfactory sugar content for an hypothetical red vinification during the trial's three year duration.

Table 3: main analytical data of musts (2015-17)

\begin{tabular}{|l|c|c|c|c|}
\hline Variety & ${ }^{\circ} \mathbf{B r i x}$ & $\mathbf{p H}$ & $\begin{array}{c}\text { TA } \\
(\mathbf{g} / \mathbf{l})\end{array}$ & $\begin{array}{c}\text { YAN } \\
(\mathbf{m g} / \mathbf{l})\end{array}$ \\
\hline Aromera & $22.1 \mathrm{ab}$ & $3.29 \mathrm{ab}$ & 5.35 & $57 \mathrm{~b}$ \\
\hline Baron & $21.9 \mathrm{ab}$ & $3.40 \mathrm{ab}$ & 5.30 & $109 \mathrm{ab}$ \\
\hline Bronner & $20.4 \mathrm{ab}$ & $3.23 \mathrm{ab}$ & 6.33 & $67 \mathrm{~b}$ \\
\hline Cab Cantor & $23.6 \mathrm{a}$ & $3.20 \mathrm{ab}$ & 6.07 & $67 \mathrm{~b}$ \\
\hline Cab Carbon & $21.6 \mathrm{ab}$ & $3.24 \mathrm{ab}$ & 6.33 & $45 \mathrm{~b}$ \\
\hline Cab Cortis & $22.5 \mathrm{a}$ & $3.14 \mathrm{~b}$ & 6.20 & $63 \mathrm{~b}$ \\
\hline Cabino & $21.9 \mathrm{ab}$ & $3.48 \mathrm{ab}$ & 5.90 & $102 \mathrm{ab}$ \\
\hline Helios & $21.3 \mathrm{ab}$ & $3.30 \mathrm{ab}$ & 5.40 & $45 \mathrm{~b}$ \\
\hline Johanniter & $19.5 \mathrm{ab}$ & $3.44 \mathrm{ab}$ & 5.75 & $167 \mathrm{a}$ \\
\hline Monarch & $17.8 \mathrm{~b}$ & $3.18 \mathrm{ab}$ & 6.48 & $49 \mathrm{~b}$ \\
\hline Muscaris & $23.7 \mathrm{a}$ & $3.38 \mathrm{ab}$ & 6.53 & $81 \mathrm{~b}$ \\
\hline Prior & $20.6 \mathrm{ab}$ & $3.32 \mathrm{ab}$ & 6.09 & $39 \mathrm{~b}$ \\
\hline Regent & $21.3 \mathrm{ab}$ & $3.60 \mathrm{a}$ & 5.75 & $176 \mathrm{a}$ \\
\hline Solaris & $23.8 \mathrm{a}$ & $3.22 \mathrm{ab}$ & 7.10 & $137 \mathrm{ab}$ \\
\hline Souvignier g. & $21.4 \mathrm{ab}$ & $3.27 \mathrm{ab}$ & 6.97 & $57 \mathrm{~b}$ \\
\hline Significance & $* *$ & $*$ & $\mathrm{~ns}$ & $*$ \\
\hline
\end{tabular}

The monitoring of the vines' health status, with particular regard to fungal disease symptoms, has described, in 2016, damages on the leaves caused by downy mildew only on Cabino and Regent, with values accounting for a 5\% of damage severity. In 2017, Cabino developed $90 \%$ damage to leaves, with significant damage also to clusters, likely greatly affecting the productivity.

\section{Conclusions}

In the pedoclimatic context of the Adige floodplain, the different cultivars have shown variable development. Regent and Baron have shown excessive vigor through a low Ravaz index and a high number of leaf layers; conversely, Cabernet Cantor, Cabernet Cortis, Cabino, Helios, and Prior have shown poor vigor. For some of these cultivars, a careful agronomic handling of fertilization and canopy management may reduce poor balance, especially in Cabino, Helios, and Prior, genotypes also showing high fractions of missing vines. Baron, Cabino, Helios, and Regent have shown low yield that compromises their economic sustainability. In addition, Cabino has revealed poor resistance to the fungal diseases and it cannot be recommended for cultivation.

The poor qualitative expression of the red berry Monarch is manifested: in fact, this variety failed to accumulate sufficient sugar content $\left(18.3^{\circ}\right.$ Brix in 2015, $16.5^{\circ}$ Brix in $2016,18.6^{\circ}$ Brix in 2017 ).

From the nutritional point of view, it is recommended to pay particular attention to $\mathrm{Mg}$ management as, despite the high soil availability of this ion at the specific site, deficiencies supported by leaf analyses showed up in Bronner, Helios, Johanniter, and Souvignier gris. In other cases, Cabernet Cantor and Monarch $\mathrm{Mg}$ deficiency was visible, although not confirmed by tissue analysis. . Consequently, $\mathrm{Mg}$ foliar treatments seem to be strongly recommended for such resistant cultivars.

\section{References}

1. T. Gomiero. App. Soil Ecol., 123, 714-728 (2018)

2. S. Román, L.M Sanchez-Siles, M. Siegris , Trends Food Sci. Tec. , 67, 44-57 (2017)

3. J. Rana, J, Paul. Journal of Retailing and Consumer Services, 38, 157-165 (2017)

4. http://www.minambiente.it/sites/default/files/archivio /normativa/dim_22_01_2014.pdf

5. https://www.piwi-international.de/it/

\footnotetext{
Corresponding author: stefano.pedo@,fmach.it
} 
6. D. H. Lorenz, K. W. Eichhorn, H. Blei-Holder, R. Klose, U. Meier Und E. Weber. Vitic. Enol. Sci., 49, 66-70 (1994)

7. R. Smart, Am. J. Enol. Viticult., 36, 230-239 (1985)

8. R. Smart, M. Robinson. Sunlight Into Wine: A Handbook for Winegrape Canopy Management. (Ed. Winetitles, Adelaide, 1991)

9. D. Porro, G. Stringari, O. Failla, A. Scienza. Acta Hortic., 564, 413-420 (2001) 